\title{
EVALUATING DANCE CONSUMPTION THROUGH THE EXPERIENTIAL VALUE APPROACH
}

\section{OCJENJIVANJE KORIŠTENJA USLUGE PLESA PRISTUPOM ISKUSTVENE VRIJEDNOSTI}

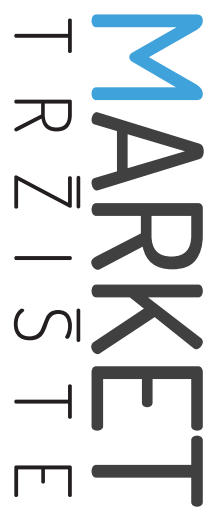

Market-Tržište

Vol. 30, No. 2, 2018, pp. 147-164

UDK 658.89-055:793.3

DOl http://dx.doi.org/10.22598/mt/2018.30.2.147

Preliminary communication

\author{
Manuel Cuadrado ${ }^{a}$, Maja Šerićc ${ }^{b}$ Martina G. Gallarzac \\ a) University of Valencia, Faculty of Economics, Valencia, Spain, e-mail: manuel.cuadrado@uv.es \\ b) University of Valencia, Faculty of Economics, Valencia, Spain, e-mail: maja.seric@uv.es \\ c) University of Valencia, Faculty of Economics, Valencia, Spain, e-mail: martina.gallarza@uv.es
}

\begin{abstract}
Purpose - The experiential paradigm has been confirmed as a valuable means to explore and understand people's consumption of cultural services, thus drawing an increasing interest in the marketing and consumer behavior literature. In this context, consumers' behavioral decisions are considered not as merely functional but also strongly influenced by emotional dimensions and intrinsic aspects. As consumption of arts is strongly associated with feelings, the experiential approach is a valuable lens for exploring and understanding individuals who consume cultural services. This paper therefore adopts the experiential approach to assess dance as a consumption experience, which is meant to be inter-subjective, i.e. different by demographic profiles. In particular, it analyzes the habits (frequency of attendance, sources of information, motives, and barriers) and attitudes (perceived value and intention) of people towards dance shows, considering different demographic profiles of respondents.
\end{abstract}

Design/Methodology/Approach - An exploratory and descriptive marketing research was undertaken after developing a literature review. The research was conducted through personal survey using a structured questionnaire. Quota sampling (age and gender) was the method used to select the sample, which comprised 672 individ-

\section{Sažetak}

Svrha - Iskustvena se paradigma pokazala značajnom u istraživanju i razumijevanju konzumacije usluga u kulturi, a time za nju raste i interes $u$ literaturi iz područja marketinga i ponašanja potrošača. $U$ ovom kontekstu odluke o ponašanju potrošača ne smatraju se samo funkcionalnima, već su snažno pod utjecajem emocionalnih dimenzija i intrinzičnih aspekata. Budući da je konzumacija umjetnosti visoko povezana s osjećajima, iskustveni pristup pruža vrijedan pogled $u$ istraživanje i razumijevanje pojedinčeve konzumacije usluga kulture. Zbog toga se u radu koristi iskustveni pristup da bi se ocijenio ples kao iskustvo potrošnje, koje se razlikuje ovisno o demografskom profilu korisnika. Analiziraju se navike ljudi (učestalost pohađanja, izvori informacija, motivi i prepreke) i stavovi (percipirana vrijednost i namjera) prema plesnim priredbama s obzirom na različite demografske profile ispitanika.

Metodološki pristup - Nakon izrade pregleda literature, provedeno je izviđajno i opisno istraživanje. Primijenjeno je osobno ispitivanje uz pomoć strukturiranog anketnog upitnika. Korišten je kvotni uzorak (s obzirom na dob i spol) koji je obuhvatio 672 ispitanika. U statističkoj obradi prikupljenih podataka primijenjene su univarijatna i multivarijatna analiza. 
uals. Univariate and multivariate analysis were conducted to statistically process the information gathered.

Findings and implications - Research results show that major differences regarding the consumption of dance may be explained by gender. Women scored higher on different motives (personal, emotional, learning) for attending such type of plays, while men scored higher on barriers (dislike, other options, misunderstanding). In addition, differences in every item of perceived value of dance were statistically significant, being higher for female survey participants. These results could be of interest to marketing decision makers in adjusting strategies to their target audiences.

Limitations - This study only offers a snapshot of the research field examined and is descriptive in nature.

Originality - Although the experiential marketing framework can be applied to many different fields thanks to its applicability, to the best of the authors' knowledge, no attempts have been made to research the habits and attitudes associated with the attendance of dance shows. The present paper addresses this issue.

Keywords - experiential marketing, consumption experience, dance, experiential value, demographic descriptors, gender
Rezultati i implikacije - Rezultati pokazuju da spol objašnjava glavne razlike pri korištenju usluge plesa. Kod žena različiti su motivi (osobni, emocionalni, učenje) postigli veće vrijednosti za sudjelovanje u takvoj vrsti aktivnosti, dok su muškarci motivirani barijerama (nesviđanjem, drugim mogućnostima, nerazumijevanjem). Osim toga, razlike u česticama koje mjere percipiranu vrijednost plesa statistički su značajne tako da su više vrijednosti za ženske ispitanike. Ovi rezultati mogu biti zanimljivi donositeljima marketinških odluka kako bi prilagodili strategije prema svojim ciljnim skupinama.

Ograničenja - Istraživanje nudi samo kratak uvid - snimak u područje istraživanja pa je po svojoj prirodi opisno.

Doprinos - lako se, zbog svoje primjenjivosti, iskustveni pristup može koristiti u različitim područjima marketinga, prema saznanjima autora, do sada nisu istraživane navike i stavovi potrošača prema posjećivanju plesnih priredbi. Stoga se rad bavi ovom problematikom.

Ključne riječi - iskustveni marketing, iskustvo konzumacije, ples, iskustvena vrijednost, demografska obilježja, spol 


\section{INTRODUCTION}

Among various paradigms in marketing and consumer behavior, the experiential perspective claims adherents among both practitioners and academics (Arnould, 2007). Not only does it encompass different disciplines, such as psychology, sociology, and management (Petermans, Janssens \& Van Cleempoel, 2013), but it is also applicable to both pre- and post-purchase consumption (Gallarza, Gil-Saura \& Holbrook, 2011; Helkkula, Kelleher \& Pihlström, 2012). The experiential approach embraces broader aspects of markets than purely economic behavior, such as religion, aesthetics, and arts (Holbrook \& Hirschman, 1982). Whilst the classical economic theory regards the consumer as a logical thinker whose purchasing decisions are based on rational problem solving, this approach advocates the exploitation of intangible and intrinsic elements linked to the emotional value perceived by customers (Gallarza et al., 2011; Holbrook, 1999; Schmitt, 1999). All these are prominent aspects of cultural consumption. Indeed, the consumption of culture and arts relates to emotions, feelings, and moods (Bigné, Andreu \& Matilla, 2008; Komarac, 2014), and within the experiential paradigm consumers should "dazzle their senses, touch their hearts, and stimulate their minds" (Schmitt, 1999: 22).

Cultural consumption is an increasingly important research area in marketing literature (Komarac, 2014). According to the Eurobarometar survey (2013), the most common method of cultural participation is by watching or listening to a cultural program on TV or radio (72\%), while the consumption of a ballet, a dance performance, or an opera seems to be rather neglected (18\%). However, dance consumption, as well as cultural practice in general, shows some interesting differences in the levels of engagement between markets. Thus, for example, in Sweden, 31 \% of respondents were more likely to attend this kind of performing arts shows (ballet, dance, and opera), while only $8 \%$ were willing to do so in Portugal or $9 \%$ in Greece and Cyprus. Furthermore, the Eurobarometar survey (2013) also showed a higher range of ages among the respondents seeing a ballet, a dance performance, or an opera, in addition to a higher education level, belonging to upper class, and living in larger towns. Finally, the main barrier to attend this kind of shows was lack of interest.

Considering the general suitability of the experiential paradigm for researching culture, in the present paper we aim at adopting the approach of experiential value to analyze the consumption of dance shows. Spectators do experience different aspects while attending this type of cultural events, which have been proved to be sophisticated and multifaceted; therefore, it is suitable for a multidimensional approach, where cognitive, affective, and social value drivers are experienced. More precisely, the purpose of this paper is to cast more light on this particular cultural setting by means of researching: a) habits (frequency of attendance, sources of information, motives, and barriers) and b) attitudes (perceived value and intentions) among the respondents of different demographic profiles.

The paper makes a twofold contribution to previous marketing literature. On the one hand, to the consumer behavior literature (where consumer value has been very deeply tackled in many settings such as tourism, retailing, education, and others), as it explores a new area of application, i.e. dance consumption, in which value-based research is scarce. On the other hand, the paper contributes to the literature on the marketing of culture and the arts by adopting the experiential approach and, more precisely, by focusing on the subjectivity of the experiential approach to dance consumption.

\section{CONSUMPTION EXPERIENCE: LITERATURE REVIEW}

\subsection{The experiential value approach to dance consumption}

Among various paradigms in marketing and consumer behavior research, the experiential perspective has been continuously revisited for 
the last three decades (Woodward \& Holbrook, 2013; Arnould, 2007). First proposed in 1982 in a seminal work in the Journal of Consumer Research by Morris B. Holbrook and Elizabeth Hirschman, the experiential approach emerged in contrast with the information-processing paradigm, widely spread in early works on marketing and consumer behavior from the 1970s and 1980s. Indeed, consumer behavior was supposed to be firstly objective and rational. However, this perspective was proven to have shortcomings as humans do not merely maximize economic utility but also look for broader experiences while shopping and consuming. Accordingly, in the experiential paradigm, consumer behavior is viewed as actions that pursue more subjective, emotional, and symbolic aspects of human behavior, positing therefore that humans can derive fantasies, feelings, and fun from their decisions as consumers in the market place (Holbrook \& Hirschman, 1982). Such approach to consumer behavior and to the way humans evaluate consumption experiences has a philosophical dimension, understood as fully phenomenological (Holbrook, 1999; Helkkula et al., 2012). In this regard, service experience is the phenomenon of "the subjective personal reactions and feelings experienced by customers when they consume a service" (Otto \& Ritchie, 1996: 165).

The experiential approach is nurtured in the classical underpinnings of consumption, such as the dichotomy between utilitarian and hedonism, but it is somehow broad enough to be applied to other consumption settings, such as arts and culture. It is a way of understanding human behavior in the marketplace, which considers that "everything is consumption" (Holbrook, 1999) and allows applications to many different contexts, such as: retailing (e.g. Babin, Darden \& Griffin, 1994; Mathwick, Malhotra \& Rigdon, 2001), vegetarian restaurants (e.g. Sánchez-Fernández, Iniesta-Bonillo \& Holbrook, 2009), consumption of electronic sports (e.g. Seo, 2013), tourism gift consumption (e.g. Clarke, 2013), or boutique hotels (e.g. Sørensen \& Jensen, 2015). Other less business-oriented realms have also been analyzed through the lens of experiential paradigm, such as the evaluations of films (e.g. Addis \& Holbrook, 2010), volunteering in religious events (e.g. Gallarza, Arteaga-Moreno, Servera-Francés \& Fayos-Gardó, 2016), or jazz music symbolism (e.g. Holbrook, 2009). However, to the best of the authors' knowledge, none of the previous works based on the experiential approach have been applied to dance consumption.

As Arnould (2007: 185) recognized: "The experiential marketing framework ... appears to incorporate a number of elements from a relatively long period of conceptualization into a potentially fruitful way of approaching today's rapidly evolving marketplaces." Based on this idea, the consumption experience of dance shows is the service setting chosen, as a "rapidly evolving marketplace". As a sophisticated art performance, dance is one of the less commonly attended art expressions (Bendinghaus, 2016). Therefore, as noted in the introduction, the aim of this paper is to prove the ability of the experiential paradigm to shed light on the multidimensional and highly personal nature of the consumption of dance shows.

\subsection{Consumer value as a key notion in the experiential approach}

The notion of value plays a key role in the experiential approach within a phenomenological perspective of consumption places (Helkkula et al., 2012; Holbrook, 1999; Gallarza et al., 2011). Value is what consumers derive from experiencing the products and services in the market. The value concept is therefore a seminal topic for the understanding of both the epistemology and the practice of marketing (Holbrook, 1999; Gallarza et al., 2011; Sweeney \& Soutar, 2001). According to Zeithaml (1988: 4), value is considered as "the overall assessment of the utility of a product based on the perceptions of what is received and what is given". This early conceptual proposal is the most universally accepted definition of consumer value. However, other authors, 
although not denying this approach in tradeoff, have favored broader and more sophisticated perspectives such as the experiential one, with Holbrook its main referent. Holbrook (1999: 5) defines value as "an interactive, relativistic, preference experience". This definition of value is referred to as axiology (that is, as a judgment of goodness/badness), thus pursuing a philosophical approach. Value is understood as interactive because it entails an interaction between subjects (consumers) and objects (products or services); it is also preferential because it embodies a preference judgment, related to affect (pleasing vs. displeasing), attitude (like vs. dislike), and/or evaluation (good vs. bad). Value is an experience because it resides not only in the product purchased or in the brand chosen but rather in the consumption experience derived therefrom. And value is relativistic because it is understood as personal (varying across people), comparative (with differences among objects), and situational (specific to the context). These last two characteristics, corresponding to the idiosyncrasy of the experiential approach, cohere with the scope of our research, which looks for differences by consumers, within an attitude-like judgment of consumption in a specific sector. Further explanation of this experiential value approach is provided in the following subsection.

\subsection{Characteristics of the experiential value approach}

Among the wide conceptual literature on the experiential value, two characteristics or propositions on the nature of experiential evaluations of value are highlighted for the purpose of this paper: multidimensionality and subjectivity.

First, experiential value is fully multidimensional (e.g. Holbrook, 1999; Sweeney \& Soutar, 2001). In the words of Holbrook (1999: 4): "One can understand a given type of value only by considering its relationship with other types of value." In this sense, viewed through experiential lens, it could be said that consumers are "multi-tasking all the time" (Woodward \& Holbrook, 2013: 3) be- cause their evaluations are based on the many dimensions of experience (functional, emotional, social, and others). The multidimensionality of value is one of the few areas of agreement in the abundant conceptual research of value. However, although authors recognize that value is multidimensional, there is no consensus on the number of dimensions or the criteria for their classification (Gallarza et al., 2011). Consequently, the range and variety of value dimensions referred to in the literature is extremely wide. Zeithaml's (1988) initial value definition leads to the consideration of two main dimensions of value: positive value dimensions or benefits from the experience, and negative value dimensions or sacrifices of the experience. However, beyond this general distinction between positive and negative values, other approaches propose more detailed value typologies, based on a more multidimensional approach, with additional axis or dichotomies (self- or other-oriented, active or reactive, etc.). Indeed, the typologies of experiential value are elaborated on utilitarian and hedonic values and emphasize the functional and affective aspects of value (e.g. Mathwick et al., 2001; Seo \& Lee, 2008; Yuan \& Wu, 2008). All these works tend to look for more refined and complex forms of classical values while adding social and sometimes even altruistic ones, showing that the experiential perspective continually renews its approaches and conceptualizations. Holbrook himself, after two decades of research, turned the experiential approach into a comprehensive conceptual framework on value (Holbrook, 1999) that accounts for eight types of experiential values: economic (efficiency, excellence), social (status, esteem), hedonic or emotional (play, aesthetics) and altruistic (ethics, spirituality).

Other relevant contributions of value dimensions have been derived from Holbrook's approach, with different value scales proposed: a) Babin and others' (1994) two-dimensional scale, utilitarian vs. hedonic values, was continuously replicated by other authors in different services (mainly retailing formats, such as malls,

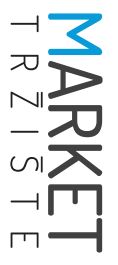


discounts, etc.); b) Sheth, Newman and Gross (1991), who proposed theoretical distinctions among five types of value - functional, social, emotional, epistemic, and conditional. A decade later, Sweeney and Soutar (2001) used this typology and produced the PERVAL scale with four dimensions (two functional ones - quality and price, one social, and one emotional; c) Mathwick and others (2001) contemplated the dimensions of Holbrook's value typology with precise interest in on- and off-line retailing formats.

Second, experiential value is highly subjective and contextual, depending on persons, objects, and circumstances. As suggested by Helkkula and others (2012: 61), "value in the experience is individually intra- subjective." Experiential approaches, irrespective of whether they are theoretical (e.g. Arnould, 2007; Holbrook \& Hirschman 1982; Woodward \& Holbrook, 2013) or empirical (e.g. Arnold \& Reynolds, 2003; Sullivan, Bonn, Bhardwaj \& DuPont, 2012), remark on the relevance of intrinsic aspects of consumption, such as personality, feelings and moods, highlighting the intrinsically personal relativity of consumption behavior. All this confirms the relevance of the experiential approach to better understand the differences among subjects in one and the same consumption experience, i.e. differences to be measured according to demographics, as proposed in the present study.

In this regard, consumer behavior literature has looked for relationships between value dimensions and groups of consumers (Kivetz \& Strahilevitz, 2001). It has found support for the existence of differences in value dimensions by gender (e.g. Andrews, Kiel, Drennan, Boyle \& Werawardeena, 2007), age (e.g. Jackson, Stoel \& Brantley, 2011), social class (e.g. Seo \& Lee, 2008), level of income (e.g. Allard, Babin \& Chebat, 2009), nationality (e.g. Lloyd, Yip \& Luk, 2011), or several demographic variables at the same time (e.g. Gallarza \& Gil-Saura, 2008). With a similar scope, but using the lens of experiential value, our study seeks to identify the differences in dance show consumption by demographics and socioeconomics. More precisely, considering the two aforementioned main features of the notion of experiential value (multidimensionality and subjectivity), we consider it interesting to explore the differences in habits and attitudes towards dance shows, according to individual characteristics of respondents (gender, age, education level, and marital status).

\section{EMPIRICAL RESEARCH}

\subsection{Research questions}

After analyzing previous literature, a descriptive marketing research, which was exploratory in nature, was carried out. The overall marketing research problem was to analyze the habits and attitudes when it comes to dance. The rationale behind the choice of variables of: a) habits (frequency of attendance, sources of information, motives, and barriers) and b) attitudes (perceived value and intentions) corresponds to the nature of the experiential approach, which is applicable to both pre- and post-purchase consumption (Gallarza et al., 2011; Helkkula et al., 2012). In particular, motives and barriers are associated with pre-phase consumption while attitude-like measures, such as perceived value and intentions, are related to post-purchase consumption. Moreover, both cognition and affection are considered in this choice of variables, as should be the case in any experiential approach (Holbrook, 1999).

Therefore, the specific objectives were formulated in the form of the following research questions:

\section{Dance consumption habits}

1.1. How often do people go to see a dance show?

1.2. When do they attend a dance performance?

1.3. Where do people consume dance plays?

1.4. What sources of information do dance spectators use? 
1.5. Why do individuals go to these events?

1.6. What stops them to attend dance shows?

\section{Attitudes among people towards dance}

2.1. What is the perceived value of dance?

2.2. What is the interest in dance?

2.3. Is there any emotional implication with dance?

2.4. Do people have any intention to attend a dance show?

\section{Classification}

3.1. What is the socio-demographic profile of respondents (gender, age, education level, marital status)?

3.2. What are the main differences in people's perception of dance shows according to demographic variables?

\subsection{Methodology}

The research was conducted in the form of personal survey using a structured questionnaire. The questionnaire was designed from previous studies measuring arts consumption habits and attitudes (e.g. Theodorakis, Goulimaris \& Gargalianos, 2003; Cuadrado-García, Pérez-Cabañero \& Montoro-Pons, 2017). It was divided into three parts following the above list of research questions (habits, attitudes, and classification variables). Five-point Likert scales were mostly used to assess all the items of different variables considered (motives, barriers, perceived value, and intentions), as suggested by previous literature. As this was an exploratory study, quota sampling was used as the method of selecting respondents from the population, with age and gender as the quotas selected. They were determined to be between 18 and 35 years old as young people seem to be the segment attending dance with less frequency (SGAE, 2017). The sample comprised 672 individuals. Data collection took place in a Spanish region in December 2015. Univariate (frequency distribution and mean) and multivariate analysis (factor analysis,
ANOVA) were applied to statistically process the information gathered.

\subsection{Sample profile}

The sample consisted of $50.6 \%$ women and $49.4 \%$ men. Most respondents were between 30 and 35 years old (42.4\%), followed by those aged between 22 and 25 (21\%) and 26 and 29 (20.8\%). The rest (15.8\%) were between 18 and 21 years old. With respect to the education level, the majority of respondents had a university degree (59.1\%), while others had a high school diploma (22.6\%), apprenticeship level qualifications (15.8\%), or middle school diploma (2.5\%). Regarding their marital status, the respondents were mainly single and without children $(40.9 \%)$ or in a relationship and without children (36.8\%). A total of $18.6 \%$ of them were in a relationship and had children, while only $3.7 \%$ were single with children.

\section{ANALYSIS AND RESULTS}

\subsection{Descriptive analysis}

\subsubsection{Habits}

The findings reveal that $59.7 \%$ of people who participated in this study have never been to a dance show, while $40.3 \%$ of them have. Among those who attended a dance show, $38.0 \%$ did that the year before, $36.1 \%$ more than two years earlier, while $25.9 \%$ of respondents attended a dance show between one and two years earlier. Their frequency of attendance was mostly less than once a year (58.6 \%) or once a year (27.8\%), and their preferred time was mainly during the weekends (51.1\%) or during vacations (23.0\%). Generally, they attended a dance show with their friends (41.2\%), family (31.3\%) or partners (23.5\%). Finally, theatres or auditoriums seem to be the preferred places for attending a dance show, followed by festivals, schools or academies, streets, and pubs or clubs. The most frequently used sources of information about such events are web pages (48.2\%), followed by recommendations of friends and family (31.6\%), and social networks (12.2\%). 
TABLE 1: Habits related with consumption of a dance show: motives and barriers

\begin{tabular}{|c|c|c|c|c|}
\hline MOTIVES & Min. & Max. & Mean & SD \\
\hline To meet with friends/family & 1 & 5 & 3.22 & 1.22 \\
\hline To feel emotions & 1 & 5 & 3.68 & 1.00 \\
\hline To see my favorite ballerina & 1 & 5 & 2.62 & 1.14 \\
\hline To enjoy a live show & 1 & 5 & 4.04 & .93 \\
\hline To see the work of a choreographer & 1 & 5 & 2.99 & 1.21 \\
\hline To fight boredom & 1 & 5 & 2.61 & 1.28 \\
\hline To have an experience & 1 & 5 & 3.79 & 1.08 \\
\hline To see well-known shows & 1 & 5 & 3.28 & 1.20 \\
\hline To relax & 1 & 5 & 3.46 & 1.10 \\
\hline To develop my personality & 1 & 5 & 3.15 & 1.22 \\
\hline To see a recommended show & 1 & 5 & 3.64 & 1.02 \\
\hline To know more about a topic & 1 & 5 & 3.13 & 1.09 \\
\hline To see premieres & 1 & 5 & 2.91 & 1.12 \\
\hline To learn other languages & 1 & 5 & 2.36 & 1.11 \\
\hline To discover other cultures & 1 & 5 & 3.29 & 1.16 \\
\hline To see a show with good reviews & 1 & 5 & 3.34 & 1.13 \\
\hline To see a well-promoted show & 1 & 5 & 3.30 & 1.14 \\
\hline BARRIERS & Min. & Max. & Mean & SD \\
\hline Lack of time & 1 & 5 & 3.00 & 1.27 \\
\hline Many other events & 1 & 5 & 2.64 & 1.16 \\
\hline Prefer other media & 1 & 5 & 2.62 & 1.26 \\
\hline Don't know the program & 1 & 5 & 3.48 & 1.16 \\
\hline I don't like (dance) & 1 & 5 & 2.70 & 1.30 \\
\hline All shows are similar & 1 & 5 & 2.48 & 1.12 \\
\hline All shows are bad & 1 & 5 & 2.20 & 1.10 \\
\hline Prefer social networking & 1 & 5 & 2.68 & 1.29 \\
\hline Prefer other events & 1 & 5 & 3.90 & 1.07 \\
\hline Prefer other things & 1 & 5 & 3.95 & 1.10 \\
\hline Prefer video games & 1 & 5 & 2.43 & 1.36 \\
\hline Too expensive & 1 & 5 & 3.32 & 1.12 \\
\hline Handier seeing shows at home & 1 & 5 & 2.65 & 1.16 \\
\hline Cannot talk in the theatre & 1 & 5 & 2.29 & 1.20 \\
\hline Cheaper ways to see shows & 1 & 5 & 2.98 & 1.16 \\
\hline Difficult to leave the house & 1 & 5 & 2.32 & 1.29 \\
\hline I don't care & 1 & 5 & 2.82 & 1.33 \\
\hline Shows are difficult to understand & 1 & 3 & 2.65 & 1.64 \\
\hline Don't have anybody to go with & 1 & 5 & 2.34 & 1.20 \\
\hline Not much information about the program & 1 & 5 & 3.02 & 1.05 \\
\hline Difficult to get tickets & 1 & 5 & 2.47 & .97 \\
\hline Theatres are far away from home & 1 & 5 & 2.80 & 1.17 \\
\hline It is not allowed to eat in the theatre & 1 & 5 & 1.92 & 1.08 \\
\hline People annoy me with their telephones & 1 & 5 & 2.21 & 1.17 \\
\hline Times they show dance are inconvenient & 1 & 5 & 2.41 & 1.07 \\
\hline Other spectators annoy me & 1 & 5 & 2.07 & 1.01 \\
\hline I don't enjoy it & 1 & 5 & 2.60 & 1.29 \\
\hline The shows are not my style & 1 & 5 & 2.93 & 1.23 \\
\hline
\end{tabular}


Regarding the motives for seeing a dance show, enjoying a live-show ( $M=4.04)$, having an experience $(M=3.79)$, feeling emotions $(M=3.68)$, and seeing a recommended show $(M=3.64)$ emerge as the most important ones; meanwhile, while learning other languages $(M=2.36)$, fighting boredom $(M=2.61)$, and seeing a favorite ballerina $(M=2.62)$ seem to be the least relevant ones (see Table 1).

On the other hand, preference for other things $(M=3.95)$ and events $(M=3.90)$, as well as lack of information about the program $(M=3.48)$ and excessive price $(M=3.32)$, emerge as the strongest barriers to attendance of a dance show. Not being able to eat $(M=1.92)$ or talk in the theatre $(M=2.29)$, general consideration of shows as bad
$(M=2.20)$, and annoyance at other spectators in general $(M=2.07)$, and with their telephones in particular $(M=2.21)$, are less important barriers to dance show consumption (see Table 1).

\subsubsection{Attitudes}

Regarding the perceived value of a dance show, it seems that dance is mostly perceived as a means for learning $(M=3.45)$ and enjoying $(M=3.31)$. Liking the look of dance shows $(M=3.20)$, showing interest $(M=3.20)$, and escaping from reality $(M=3.20)$, are among other items that received relatively higher scores, with social acceptance $(M=2.43)$, social self-image $(M=2.54)$, and social appreciation $(M=2.59)$ as the lowest assessed items (see Table 2).

TABLE 2: Attitudes related with consumption of a dance show: perceived value and intentions

\begin{tabular}{|l|c|c|c|c|}
\hline PERCEIVED VALUE & Min. & Max. & Mean & SD \\
\hline I leave a good impression among others & 1 & 5 & 2.83 & 1.11 \\
\hline I become socially appreciated & 1 & 5 & 2.59 & 1.06 \\
\hline I become socially accepted & 1 & 5 & 2.43 & 1.08 \\
\hline Others think better of me & 1 & 5 & 2.54 & 1.10 \\
\hline I enjoy seeing dance shows & 1 & 5 & 3.31 & 1.12 \\
\hline I feel better after attending a dance show & 1 & 5 & 3.24 & 1.12 \\
\hline I like the form in which a dance show is presented & 1 & 5 & 3.17 & 1.07 \\
\hline I like the look of dance shows & 1 & 5 & 3.25 & 1.02 \\
\hline It helps me to escape the real world for a short time & 1 & 5 & 3.20 & 1.16 \\
\hline I can forget everything else for a while & 1 & 5 & 3.07 & 1.15 \\
\hline By attending a dance show, I show interest & 1 & 5 & 3.20 & 1.03 \\
\hline I can learn new things & 1 & 5 & 3.45 & 1.09 \\
\hline INTENTIONS & $\mathbf{M i n}$. & $\mathbf{M a x}$ & $\mathbf{M e a n}$ & SD \\
\hline Say positive things about dance shows & 1 & 5 & 3.13 & 1.02 \\
\hline Recommend dance shows & 1 & 5 & 3.12 & 1.59 \\
\hline Encourage my friends and family to go & 1 & 5 & 3.12 & 1.07 \\
\hline Dance shows are my preferred cultural activity & 1 & 5 & 2.17 & 1.12 \\
\hline See more dance shows & 1 & 5 & 2.96 & 1.14 \\
\hline See fewer dance shows & 1 & 5 & 2.54 & 1.10 \\
\hline Attend cheaper cultural activities & 1 & 5 & 3.60 & 1.08 \\
\hline Continue to go to dance shows if prices increase & 1 & 5 & 2.32 & 1.05 \\
\hline Pay more if dance shows provide benefits for me & 1 & 5 & 2.47 & 1.14 \\
\hline $\begin{array}{l}\text { Go to other cultural activities in case of a bad experience at a } \\
\text { dance show }\end{array}$ & 1 & 5 & 3.19 & 1.10 \\
\hline Complain about a bad experience to other spectators & 1 & 5 & 2.81 & 1.12 \\
\hline Complain about a bad experience to other entities & 1 & 5 & 2.60 & 1.06 \\
\hline Complain about a bad experience to venue employees & & 2.53 & 1.11 \\
\hline
\end{tabular}


On the other hand, the intention to attend cheaper cultural activities $(M=3.60)$ is the highest scored intentions item, while preference for dance shows over other cultural activities $(M=2.17)$ and intention to go to dance shows if prices increases $(M=2.32)$ emerge as the lowest evaluated intention aspects (see Table 2).

\subsection{Factor analysis}

Factor analysis was conducted not only to examine the dimensionality of the previous items to measure motives, barriers, perceived value, and intention towards dance consumption, but also for operational reasons. The Kaiser-Meyer-Olkin (KMO) measure of sampling adequacy and Bartlett's sphericity test were considered first. In the case of motives, KMO came in at
0.83, while the significance level of Bartlett's test equaled 0.000 , thus indicating that information provided by the initial items can be summarized in a few factors. A principal component analysis was conducted then, resulting in five extracted components, which explained more than $60 \%$ of the variance. The extracted factors are labeled as follows: play, feelings, learning, interests, and sociability (see Table 3).

For barriers, $\mathrm{KMO}$ and Bartlett's test values (0.89 and 0.000 , respectively) also showed that the principal component analysis was appropriate. Seven components were extracted from these variables, namely, disliking, other ways, inconvenience, costs, other preferences, lack of knowledge, and restrictions, also explaining more than $60 \%$ of the variance (see Table 4).

TABLE 3: Factor analysis for motives

\begin{tabular}{|l|c|c|c|c|c|}
\hline \multirow{2}{*}{ ITEMS } & \multicolumn{5}{|c|}{ FACTORS } \\
\cline { 2 - 6 } & $\mathbf{1}$ & $\mathbf{2}$ & $\mathbf{3}$ & $\mathbf{4}$ & $\mathbf{5}$ \\
\hline To meet with friends/family & -.136 & .076 & -.061 & .091 & $\mathbf{. 7 9 3}$ \\
\hline To feel emotions & .051 & $\mathbf{. 7 8 5}$ & .119 & .068 & -.005 \\
\hline To see my favorite ballerina & .174 & .079 & .048 & $\mathbf{. 8 5 1}$ & .113 \\
\hline To enjoy a live show & .290 & $\mathbf{. 7 6 7}$ & -.015 & .083 & -.190 \\
\hline To see the work of a choreographer & .237 & .244 & .182 & $\mathbf{. 7 0 9}$ & -.171 \\
\hline To fight boredom & .226 & -.108 & .038 & -.138 & $\mathbf{. 5 6 0}$ \\
\hline To have an experience & .331 & $\mathbf{. 4 6 1}$ & .126 & .059 & .438 \\
\hline To see well-known shows & $\mathbf{. 7 0 5}$ & .112 & .109 & .235 & -.071 \\
\hline To relax & .153 & $\mathbf{. 5 4 7}$ & .177 & .094 & .363 \\
\hline To develop my personality & .037 & $\mathbf{. 5 0 3}$ & .403 & .197 & .049 \\
\hline To see a recommended show & $\mathbf{. 7 5 3}$ & .242 & .104 & -.049 & -.008 \\
\hline To know more about a topic & .386 & .130 & $\mathbf{. 5 7 4}$ & .081 & .083 \\
\hline To see premieres & $\mathbf{. 6 4 2}$ & -.142 & .359 & .354 & .014 \\
\hline To learn other languages & .069 & -.006 & $\mathbf{. 8 2 9}$ & .157 & -.041 \\
\hline To discover other cultures & .122 & .332 & $\mathbf{. 6 9 8}$ & -.046 & .016 \\
\hline To see a show with good reviews & $\mathbf{. 7 5 1}$ & .166 & .188 & .075 & .131 \\
\hline To see a well-promoted show & $\mathbf{. 7 2 3}$ & .134 & -.014 & .162 & .182 \\
\hline
\end{tabular}

Note: $1=$ play, 2 =feelings, $3=$ =earning, 4=interests, 5=sociability Extraction method: Principal Component Analysis.

Rotation method: Varimax with Kaiser Normalization. 
TABLE 4: Factor analysis for barriers

\begin{tabular}{|c|c|c|c|c|c|c|c|}
\hline \multirow{2}{*}{ ITEMS } & \multicolumn{7}{|c|}{ FACTORS } \\
\hline & 1 & 2 & 3 & 4 & 5 & 6 & 7 \\
\hline Lack of time & .027 & .162 & .066 & -.026 & .095 & .241 & .700 \\
\hline Many other events & .047 & .251 & -.009 & -.042 & -.047 & .639 & .211 \\
\hline Prefer other media & .078 & .662 & .109 & -.051 & .146 & .185 & .183 \\
\hline Don't know the program & .047 & .263 & -.061 & .335 & .279 & .483 & -.006 \\
\hline I don't like (dance) & .837 & .073 & .036 & .001 & .207 & .047 & .021 \\
\hline All shows are similar & .731 & .246 & .034 & .112 & -.038 & .058 & .055 \\
\hline All shows are bad & .756 & .262 & .104 & .125 & -.185 & .065 & .073 \\
\hline Prefer social networking & .420 & .540 & .126 & .130 & .151 & .044 & -.086 \\
\hline Prefer other events & .243 & .163 & -.052 & .045 & .794 & .056 & -.053 \\
\hline Prefer other things & .383 & .195 & -.136 & .065 & .709 & .042 & .017 \\
\hline Prefer video games & .472 & .375 & .116 & .020 & .110 & .055 & -.249 \\
\hline Too expensive & .043 & .409 & -.045 & .571 & .069 & -.220 & -.066 \\
\hline Handier seeing shows at home & .194 & .664 & .131 & .089 & .084 & .047 & .278 \\
\hline Cannot talk in the theatre & .190 & .593 & .307 & .159 & -.109 & .167 & .032 \\
\hline Cheaper ways to see shows & .023 & .637 & .241 & .259 & .158 & .019 & .078 \\
\hline Difficult to leave the house & .113 & .156 & .156 & .259 & -.183 & -.193 & .638 \\
\hline I don't care & .778 & .082 & .079 & -.032 & .283 & .158 & .038 \\
\hline Shows are difficult to understand & .310 & -.049 & .042 & .162 & .097 & .603 & -.036 \\
\hline Don't have anybody to go with & .231 & .075 & .222 & .402 & -.057 & .392 & -.156 \\
\hline Lack of information about the program & .015 & -.046 & .059 & .628 & .234 & .339 & -.122 \\
\hline Difficult to get tickets & .132 & .115 & .233 & .628 & -.099 & .074 & .125 \\
\hline Theatres are far away from home & -.030 & .083 & .195 & .664 & .034 & .078 & .254 \\
\hline It is not allowed to eat in the theatre & .198 & .357 & .613 & -.005 & -.149 & .077 & -.028 \\
\hline People annoy me with their telephones & .070 & .168 & .801 & .118 & -.064 & -.064 & -.018 \\
\hline Times they show dance are inconvenient & .065 & .090 & .688 & .253 & -.006 & .044 & .195 \\
\hline Other spectators annoy me & .177 & .129 & .808 & .099 & .068 & .035 & .083 \\
\hline I don't enjoy it & .765 & -.015 & .257 & .002 & .282 & .100 & .086 \\
\hline The shows are not my style & .636 & -.034 & .211 & .087 & .433 & .143 & .053 \\
\hline
\end{tabular}

Note: $1=$ disliking, $2=$ other ways, $3=$ inconvenience, $4=$ costs, $5=$ other preferences, $6=$ lack of knowledge, $7=$ restrictions. Extraction method: Principal Component Analysis.

Rotation method: Varimax with Kaiser Normalization.

When it comes to perceived value, once more $\mathrm{KMO}$ and Bartlett's test showed acceptable scores (0.89 and 0.000, respectively). This time principal component analysis resulted in two factors, explaining more than $67 \%$ of the variance. These factors are labeled as show effects (joy, liking, escapism, learning) and others' assessment (see Table 5). 
TABLE 5: Factor analysis of perceived value

\begin{tabular}{|l|c|c|}
\hline \multirow{2}{*}{ ITEMS } & \multicolumn{2}{|c|}{ FACTORS } \\
\cline { 2 - 3 } & $\mathbf{1}$ & $\mathbf{2}$ \\
\hline $\begin{array}{l}\text { I leave a good impression } \\
\text { among others }\end{array}$ & .289 & $\mathbf{. 8 0 6}$ \\
\hline I become socially appreciated & .173 & $\mathbf{. 8 9 4}$ \\
\hline I become socially accepted & .141 & $\mathbf{. 8 8 8}$ \\
\hline Others think better of me & .183 & $\mathbf{. 8 5 2}$ \\
\hline I enjoy seeing dance shows & $\mathbf{. 7 9 4}$ & .165 \\
\hline $\begin{array}{l}\text { I feel better after attending a } \\
\text { dance show }\end{array}$ & $\mathbf{. 8 3 3}$ & .166 \\
\hline $\begin{array}{l}\text { I like the form in which a dance } \\
\text { show is presented }\end{array}$ & $\mathbf{. 7 9 9}$ & .111 \\
\hline I like the look of dance shows & $\mathbf{. 7 9 8}$ & .143 \\
\hline $\begin{array}{l}\text { It helps me to escape the real } \\
\text { world for a short time }\end{array}$ & $\mathbf{. 7 4 7}$ & .214 \\
\hline $\begin{array}{l}\text { I can forget everything else for } \\
\text { a while }\end{array}$ & $\mathbf{. 7 5 2}$ & .204 \\
\hline $\begin{array}{l}\text { With attending a dance show I } \\
\text { show interest }\end{array}$ & $\mathbf{. 7 6 7}$ & .189 \\
\hline I can learn new things & $\mathbf{. 6 2 6}$ & .185 \\
\hline
\end{tabular}

Note: $1=$ show effects, $2=$ others' assessment.

Extraction method: Principal Component Analysis.

Rotation method: Varimax with Kaiser Normalization.

Finally, as shown in Table 6, factor analysis was carried out for intentions. KMO scored 0.77 , while the significance level of Bartlett's test was 0.000. Four components were extracted from the principal component analysis. According to the variables loading in each factor, they were labeled as follows: recommendation, complaint, more shows, and other alternatives. They explained $64 \%$ of the variance.

TABLE 6: Factor analysis for intentions

\begin{tabular}{|l|c|c|c|c|}
\hline \multirow{2}{*}{ ITEM } & \multicolumn{4}{|c|}{ FACTORS } \\
\cline { 2 - 5 } & $\mathbf{1}$ & $\mathbf{2}$ & $\mathbf{3}$ & $\mathbf{4}$ \\
\hline $\begin{array}{l}\text { Say positive things } \\
\text { about dance shows }\end{array}$ & $\mathbf{. 7 9 9}$ & -.028 & .224 & .050 \\
\hline $\begin{array}{l}\text { Recommend dance } \\
\text { shows }\end{array}$ & $\mathbf{. 7 6 3}$ & .103 & .021 & -.110 \\
\hline $\begin{array}{l}\text { Encourage my } \\
\text { friends and family } \\
\text { to go }\end{array}$ & $\mathbf{. 8 1 2}$ & -.042 & .270 & -.050 \\
\hline
\end{tabular}

\begin{tabular}{|l|c|c|c|c|}
\hline \multirow{2}{*}{ ITEM } & \multicolumn{4}{|c|}{ FACTORS } \\
\cline { 2 - 5 } & $\mathbf{1}$ & $\mathbf{2}$ & $\mathbf{3}$ & $\mathbf{4}$ \\
\hline $\begin{array}{l}\text { Dance shows } \\
\text { are my preferred } \\
\text { cultural activity }\end{array}$ & $\mathbf{. 5 0 0}$ & .069 & .459 & -.308 \\
\hline $\begin{array}{l}\text { See more dance } \\
\text { shows }\end{array}$ & .480 & -.151 & $\mathbf{. 6 2 9}$ & .028 \\
\hline $\begin{array}{l}\text { See less dance } \\
\text { shows }\end{array}$ & -.238 & $\mathbf{. 3 5 6}$ & -.405 & -.160 \\
\hline $\begin{array}{l}\text { Attend cheaper } \\
\text { cultural activities }\end{array}$ & .015 & .119 & -.286 & $\mathbf{. 7 1 1}$ \\
\hline $\begin{array}{l}\text { Continue to go } \\
\text { to dance shows if } \\
\text { prices increase }\end{array}$ & .146 & .104 & $\mathbf{. 7 2 3}$ & -.285 \\
\hline $\begin{array}{l}\text { Pay more if dance } \\
\text { shows provide } \\
\text { benefits for me }\end{array}$ & .123 & .077 & $\mathbf{. 7 8 5}$ & .004 \\
\hline $\begin{array}{l}\text { Go to other cultural } \\
\text { activities in case of a } \\
\text { bad experience at a } \\
\text { dance show }\end{array}$ & -.164 & .318 & .113 & $\mathbf{. 7 3 9}$ \\
\hline $\begin{array}{l}\text { Complain about a } \\
\text { bad experience to } \\
\text { other spectators }\end{array}$ & -.015 & $\mathbf{. 7 0 9}$ & .062 & .348 \\
\hline $\begin{array}{l}\text { Complain about a } \\
\text { bad experience to } \\
\text { other entities }\end{array}$ & .052 & $\mathbf{. 8 8 1}$ & .030 & .171 \\
\hline $\begin{array}{l}\text { Complain about a } \\
\text { bad experience to } \\
\text { venue employees }\end{array}$ & .051 & $\mathbf{. 8 4 5}$ & -.013 & .022 \\
\hline
\end{tabular}

Note: $1=$ Recommendation, $2=$ Complaint, $3=$ More shows. 4=Other alternatives.

Extraction Method: Principal Component Analysis. Rotation Method: Varimax with Kaiser Normalization.

\subsection{T-test and ANOVA}

Factors obtained were analyzed on the total sample and different subsamples according to the gender, age, education level, and marital status. Results showed that gender moderated all the examined components most significantly, as discussed below.

When dividing the sample according to gender, T-test revealed significant differences for all the motives, expect for sociability, with women being more motivated than men. When barriers to 


\begin{tabular}{|c|c|c|c|c|c|c|c|c|c|c|c|c|c|c|c|c|c|c|}
\hline & a & $\begin{array}{l}\text { ஓ. } \\
\text { ছ. }\end{array}$ & 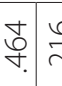 & $\frac{0}{v}$ & \begin{tabular}{l|l}
$\infty$ & \\
0 \\
0
\end{tabular} & 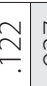 & $\hat{n}$ & \begin{tabular}{l|l} 
& \\
$\infty$ & \\
0 & \\
0 &
\end{tabular} & \begin{tabular}{l|l}
$m$ & \multirow{2}{*}{} \\
$m$ & $\infty$ \\
\end{tabular} & \begin{tabular}{l|l}
$t$ & $\stackrel{\sim}{n}$ \\
0 & $\stackrel{n}{m}$
\end{tabular} & $\begin{array}{l}m \\
\infty \\
0\end{array}$ & $\begin{array}{l}* \\
8 \\
8 \\
\end{array}$ & $\stackrel{\infty}{\searrow}$ & $\frac{n}{\hat{b}}$ & $\frac{1}{6}$ & \begin{tabular}{|l|}
$\infty$ \\
$\infty$ \\
$n$ \\
$n$
\end{tabular} & $\hat{\imath}$ & $\stackrel{\infty}{\circ}$ \\
\hline & ப & $\bar{\infty}$ & \begin{tabular}{l|l}
$\infty$ & \\
$\infty$ &
\end{tabular} & 요 & ָָे & $\stackrel{\Omega}{\underline{.}}$ & $\stackrel{\Xi}{\Xi}$ & ㅇำ & $\because$ & $\stackrel{0}{\rightleftarrows}$ & $\underset{\sim}{\sim}$ & $\begin{array}{l}\stackrel{n}{\sigma} \\
b\end{array}$ & શે & Е? & ஜి & $\hat{\sigma}$ & ㄴ? & $\underset{c}{\tau}$ \\
\hline & ด & $\begin{array}{lll}\infty & 1 \\
\infty\end{array}$ & $\stackrel{\curvearrowleft}{\cong}$ & ১. & ర్. & 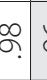 & ஜํ. & - & \begin{tabular}{c|l}
$\infty$ & \multirow{N}{*}{} \\
\end{tabular} & $\stackrel{0}{0}$ & চ্. & క. & ळ. & ন & প! & 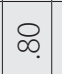 & б̄ & n \\
\hline & 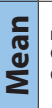 & $\stackrel{\sim}{\sim} \underset{m}{m}$ & 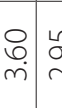 & $\stackrel{\substack{\alpha \\
\sim}}{\sim}$ & $\overline{\mathrm{N}}$ & 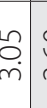 & 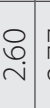 & $\stackrel{\vec{v}}{\vec{i}}$ & $\frac{\infty}{i} \underset{c}{\infty}$ & $\begin{array}{l}\stackrel{\sim}{\infty} \\
\dot{m} \\
\dot{m}\end{array}$ & নু & $\stackrel{\text { مे }}{\sim}$ & Эิ & $\begin{array}{l}\stackrel{\sim}{0} \\
\stackrel{\sim}{N}\end{array}$ & $\begin{array}{l}\infty \\
\text { i }\end{array}$ & \begin{tabular}{l}
$\varnothing$ \\
\hdashline \\
$ن$
\end{tabular} & $\begin{array}{l}\tilde{v} \\
\stackrel{v}{v}\end{array}$ & ڤે \\
\hline & 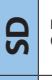 & ז. & $\bar{\kappa}$. & $\infty$. & ô. & $\bar{a}$ & बू. & চ & \begin{tabular}{l|l}
$\infty$ \\
$\infty$
\end{tabular} & นุ? & $\underset{\sim}{\cong}$ & $\begin{array}{l}\infty \\
\infty .\end{array}$ & ৪! & бฺ & $\stackrel{\text { n }}{\rightleftarrows}$ & $\begin{array}{c}m \\
\infty\end{array}$ & $\infty$ & $\begin{array}{l}\infty \\
\infty \\
\infty\end{array}$ \\
\hline & $\begin{array}{l}\frac{5}{0} \\
0 \\
\substack{1 \\
\Sigma}\end{array}$ & $\stackrel{\stackrel{\sim}{\sim}}{m}$ & \begin{tabular}{l|l}
$\stackrel{+}{n}$ & 0 \\
$m$ & $?$ \\
$m$ & $r$
\end{tabular} & \begin{tabular}{l|l}
$a$ & 5 \\
vi & 5
\end{tabular} & $\begin{array}{l}\bar{\infty} \\
\stackrel{i}{ }\end{array}$ & 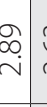 & \begin{tabular}{l|l}
$\tilde{b}$ & \\
$\dot{i}$ &
\end{tabular} & \begin{tabular}{l|l}
$o$ \\
$\dot{v}$ \\
$v$
\end{tabular} & 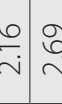 & $\begin{array}{l}\stackrel{\varnothing}{m} \\
\text { m. }\end{array}$ & Oे. & 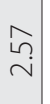 & $\overline{\bar{m}}$ & $\stackrel{n}{\sim}$ & $\begin{array}{l}\infty \\
\infty \\
\stackrel{\sim}{\sim}\end{array}$ & 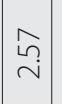 & 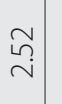 & ชे \\
\hline $\mathbf{v}$ & 只 & $\infty$ & পి. & $\bar{\infty}$. & $\stackrel{m}{n}$ & $\begin{array}{l}\infty \\
\infty \\
\infty\end{array}$ & চ & 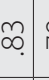 & a & $\stackrel{8}{-}$ & $\underset{\infty}{\infty}$ & $\begin{array}{l}\sim \\
\infty\end{array}$ & $\stackrel{0}{\stackrel{1}{r} .}$ & ชิ & શ. & $\cong$ & 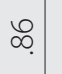 & $\infty$ \\
\hline & 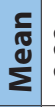 & $\underset{m}{m}$ & 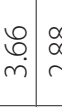 & \begin{tabular}{c|c}
$\infty$ & \\
$\infty$ & $i$ \\
$ن$ &
\end{tabular} & $\bar{\nabla}$ & 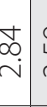 & $\stackrel{\substack{n \\
\sim}}{\sim}$ & 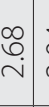 & $\begin{array}{lll}\dot{U} \\
\dot{v}\end{array}$ & $\begin{array}{l}\stackrel{n}{\hat{n}} \\
\text { ma }\end{array}$ & $\begin{array}{l}\stackrel{\llcorner}{\infty} \\
\sim \\
\sim\end{array}$ & $\stackrel{\bar{m}}{\sim}$ & $\begin{array}{l}\stackrel{\infty}{N} \\
m\end{array}$ & $\curvearrowright$ & ڤે & $\begin{array}{l}\infty \\
\stackrel{\infty}{n} \\
\sim\end{array}$ & $\begin{array}{l}\bar{\sigma} \\
\stackrel{\sim}{v}\end{array}$ & $\stackrel{m}{\forall}$ \\
\hline $\mathbf{v}$ & 只 & 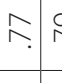 & $\stackrel{2}{\wedge}$ & $\begin{array}{lll}\hat{o} & \\
- & 1 & \\
\end{array}$ & $\stackrel{\infty}{\infty}$ & $\begin{array}{c}m \\
\infty \\
\infty\end{array}$ & & 9 & 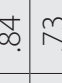 & ৪ุ & ळ. & $\hat{\delta}$ & $\stackrel{\llcorner}{\infty}$. & م઼ & $\infty$. & a & $\stackrel{\infty}{\stackrel{\infty}{n} .}$ & $\overline{0}$ \\
\hline & 孚 & $\begin{array}{lll}\infty & 0 \\
\stackrel{+}{+} & ?\end{array}$ & 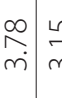 & $\frac{\sim n}{m}$ & $\begin{array}{l}a \\
m\end{array}$ & 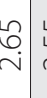 & 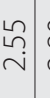 & \begin{tabular}{c|c}
8 \\
$\infty$ \\
\end{tabular} & $\underset{\widetilde{v}}{\bar{v}} \tilde{\vartheta}$ & $\begin{array}{l}\underset{\leftarrow}{Ð} \\
\dot{\forall}\end{array}$ & $\begin{array}{l}\infty \\
\stackrel{\infty}{\sim}\end{array}$ & $\begin{array}{c}\stackrel{\infty}{+} \\
\sim\end{array}$ & $\stackrel{\bullet}{\sim}$ & $m$ & $\begin{array}{c}\bar{\infty} \\
\sim \\
\sim\end{array}$ & $\begin{array}{l}\mathfrak{V} \\
\stackrel{1}{*}\end{array}$ & $\stackrel{*}{n}$ & \\
\hline 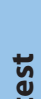 & 2 & $\begin{array}{l}* \\
\stackrel{*}{o} \\
\varnothing\end{array}$ & $\begin{array}{lll}* & * \\
8 & * \\
8\end{array}$ & \begin{tabular}{l}
$*$ \\
\multirow{2}{*}{} \\
$\varnothing$ \\
\\
\end{tabular} & * & $\stackrel{\sim}{\sim}$ & $\begin{array}{l}* \\
8 \\
8 \\
8\end{array}$ & \begin{tabular}{c|c}
$\circ$ \\
f.
\end{tabular} & 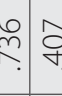 & $\frac{*}{\sigma}$ & 烍 & $\begin{array}{l}\infty \\
\infty \\
\stackrel{1}{\sim}\end{array}$ & 艾 8 & 웅 & * 8 & $\stackrel{\leftrightarrow}{f}$ & ○. & $\curvearrowright$ \\
\hline & ᄂ & 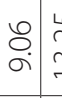 & 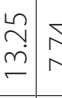 & 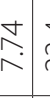 & $\stackrel{+}{\underset{\sim}{\sim}}$ & $\begin{array}{l}m \\
\stackrel{\sim}{\leftarrow} \\
\end{array}$ & $\begin{array}{l}0 \\
\dot{+} \\
\dot{v} \\
0\end{array}$ & กิ & $E \curvearrowright$ & $\begin{array}{l}\text { oे. } \\
\text { ठै. }\end{array}$ & $\begin{array}{l}\stackrel{n}{\sigma} \\
\text { mat }\end{array}$ & 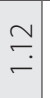 & $\begin{array}{l}\overline{1} \\
8 \\
8\end{array}$ & $\begin{array}{l}\bar{\sigma} \\
\stackrel{+}{\leftarrow}\end{array}$ & \begin{tabular}{l}
$\bar{n}$ \\
\multirow{\gamma}{*}{}
\end{tabular} & $\begin{array}{l}\text { ๙ } \\
\text { ஸุ }\end{array}$ & $\infty$ & \\
\hline 7 & и & $\stackrel{n}{\wedge}$. & 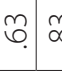 & $\begin{array}{c}m \\
\infty \\
\infty\end{array}$ & চ़! & 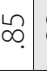 & $\begin{array}{l}\infty \\
\infty \\
\infty\end{array}$ & ๑. & $\begin{array}{l}\infty \\
\infty\end{array}$ & ஜุ & $\stackrel{\infty}{\infty}$ & Oֵ. & $\bar{\infty}$ & ஜ ? & ผn & a & ৫. & $\begin{array}{l}\bullet \\
\infty\end{array}$ \\
\hline & 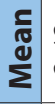 & $\begin{array}{l}\stackrel{v}{+} \\
\dot{m}\end{array}$ & 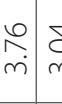 & \begin{tabular}{l|l} 
Dे & \\
$m$ &
\end{tabular} & 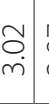 & & $\bar{m}$ & $\begin{array}{l}m \\
\underset{\sim}{N}\end{array}$ & \begin{tabular}{l|l}
+ \\
$ن$
\end{tabular} & $\begin{array}{l}m \\
\infty \\
m \\
m\end{array}$ & $\begin{array}{l}\stackrel{\llcorner}{\infty} \\
\stackrel{\sim}{\sim}\end{array}$ & $\begin{array}{c}\stackrel{2}{\mathrm{i}} \\
\mathrm{N}\end{array}$ & $\begin{array}{l}\stackrel{\infty}{+} \\
\text { m. }\end{array}$ & 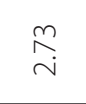 & $\stackrel{\sim}{\stackrel{\sim}{m}}$ & $\begin{array}{l}\stackrel{8}{0} \\
ن\end{array}$ & $r$ & \\
\hline & 只 & ă & \begin{tabular}{c|c}
$m$ & \\
$\infty$ & $\alpha$
\end{tabular} & 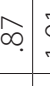 & $\underset{0}{\sigma}$ & $\begin{array}{l}\text { J. } \\
- \\
-\end{array}$ & $\stackrel{n}{\kappa}$ & $\underset{\infty}{\infty}$. & \begin{tabular}{l|l}
$\infty$ & \\
$\infty$
\end{tabular} & ু & ฮิ. & के & $\begin{array}{l}m \\
\infty\end{array}$ & চু & $\stackrel{\llcorner}{\infty}$ & $\infty$ & $\infty$ & 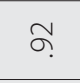 \\
\hline & $\begin{array}{l}\frac{5}{0} \\
\substack{0 \\
\Sigma}\end{array}$ & $\frac{\circ}{\dot{m}}$ & $\begin{array}{c}\stackrel{m}{f} \\
\dot{m}\end{array}$ & 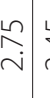 & 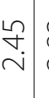 & $\begin{array}{c}m \\
\infty \\
\sim \\
\sim\end{array}$ & $\begin{array}{l}\infty \\
\infty \\
\end{array}$ & $\begin{array}{ll}\infty \\
\stackrel{1}{v} \\
\end{array}$ & $\begin{array}{ll}0 \\
v & n \\
v\end{array}$ & $\begin{array}{l}\text { Oै } \\
\stackrel{+}{*}\end{array}$ & $\begin{array}{l}8 \\
\text { m. }\end{array}$ & $\begin{array}{l}\stackrel{v}{\sigma} \\
\stackrel{v}{v}\end{array}$ & Дે & 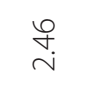 & 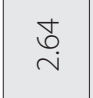 & 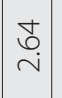 & & \\
\hline & 은 & $\stackrel{\sim}{\infty}$ & $\stackrel{m}{\wedge}$ & œ. & ৪.. & ๓ุ. & ํㅗ & চ & $\begin{array}{lll} \\
\end{array}$ & ळం & n̆ & 8 & $\infty$ & ชै & n̆ & হ & $\infty$ & \\
\hline & 亭 & 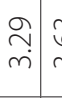 & \begin{tabular}{l|l}
$m$ & \multicolumn{1}{c}{} \\
$\dot{n}$ & $\tilde{\sigma}$
\end{tabular} & $\begin{array}{l}m \\
\stackrel{n}{i}\end{array}$ & 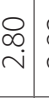 & ָે & $\stackrel{\leftrightarrow}{\sim}$ & $\stackrel{n}{\stackrel{n}{i}}:$ & 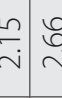 & $\begin{array}{l}\text { مे } \\
\text { mे }\end{array}$ & ๙ે & $\begin{array}{l}\text { ְ. } \\
\stackrel{\sim}{ }\end{array}$ & 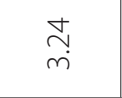 & 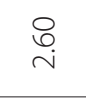 & $\begin{array}{l}\infty \\
\infty \\
\sim\end{array}$ & $\begin{array}{l}\mathfrak{v} \\
\stackrel{2}{v}\end{array}$ & $\begin{array}{l}\stackrel{a}{n} \\
\text { N }\end{array}$ & \\
\hline & ㄴ. & $\frac{\pi}{a}$ & 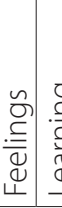 & 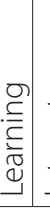 & 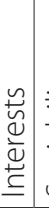 & & 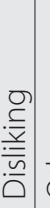 & 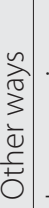 & 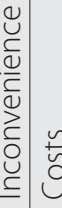 & 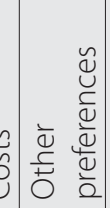 & 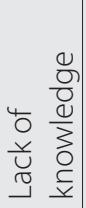 & 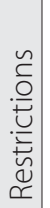 & 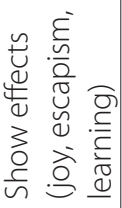 & 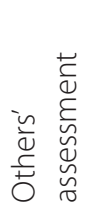 & 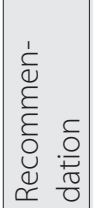 & 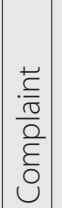 & 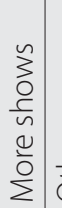 & 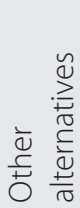 \\
\hline & & & & & & & & & & 17 & & & $\begin{array}{r}\exists \digamma \\
0 \exists \Lambda\end{array}$ & Agd & & & & \\
\hline
\end{tabular}

ஸุ Иิ ๓ 


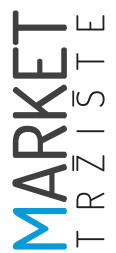

\begin{tabular}{|c|c|c|c|c|c|c|c|c|c|c|c|c|c|c|c|c|c|c|}
\hline \multirow{2}{*}{ 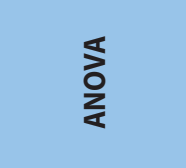 } & 0 & $\curvearrowright$ & $\begin{array}{c}\widehat{\infty} \\
\infty \\
\infty\end{array}$ & 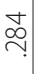 & $\begin{array}{l}0 \\
\text { ô. }\end{array}$ & 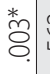 & 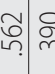 & 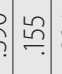 & 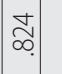 & 莒 & ஜֶণ & \begin{tabular}{|l|}
$*$ \\
\multirow{2}{*}{} \\
8 \\
8 \\
\end{tabular} & $\approx$ & $\underset{\mathbb{J}}{\stackrel{ \pm}{*}}$ & గ్రి & $\underset{\sim}{\simeq}$ & 。. & 옹 \\
\hline & ப & $\stackrel{m}{m}$ & $\bar{\tau}$ & 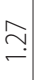 & $\cong$ & 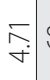 & 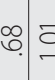 & 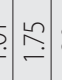 & m! & $\stackrel{\bar{\sigma}}{i}$ & $\stackrel{n}{\sim}$ & 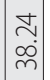 & $\stackrel{ㄴ}{\Re}$ & 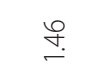 & 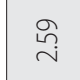 & & กิ & $\cong$ \\
\hline \multirow{2}{*}{ 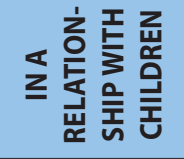 } & 으 & $\sigma$ & $\begin{array}{l}\infty \\
\stackrel{\infty}{*}\end{array}$ & ১. & ○. & 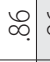 & $\infty$ \ & $\approx$ & $\overline{6}$ & बे & $\stackrel{m}{\vDash}$ & $\stackrel{\sigma}{-}$ & $\infty_{\infty}^{\infty}$ & తి & ๙ૅ & $\bar{\infty}$. & $\begin{array}{l}\text { o. } \\
\infty\end{array}$ & ळ. \\
\hline & 胥 & $\stackrel{\stackrel{一}{m}}{m}$ & $\begin{array}{l}\infty \\
\stackrel{\infty}{p} \\
\stackrel{n}{2}\end{array}$ & $\overline{\bar{m}}$ & 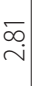 & 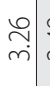 & $\stackrel{\substack{\sim \\
\sim}}{\infty}$ & 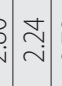 & 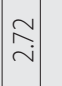 & $\underset{n}{\stackrel{N}{r}}$ & 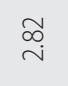 & $\stackrel{\substack{n \\
m}}{m}$ & $\stackrel{\stackrel{m}{m}}{m}$ & 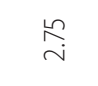 & $\stackrel{d}{\dot{m}}$ & $\underset{\sim}{\stackrel{\curvearrowright}{\sim}}$ & 苗 & 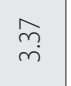 \\
\hline \multirow{2}{*}{ ¿ } & 으 & $\infty$ & $\approx$ & 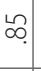 & 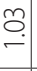 & $\infty$ & $\stackrel{8}{-\infty}$ & c. & $\stackrel{\infty}{\infty}$ & $\stackrel{\eta}{\ominus}$ & চ & $\bar{\sigma}$ & $\begin{array}{l}\infty \\
\infty\end{array}$ & ஜ! & $\infty$ & $\stackrel{n}{\wedge}$ & 怘. & $\bar{\sigma}$ \\
\hline & 趂 & 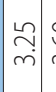 & $\begin{array}{l}\stackrel{8}{0} \\
\text { mi. }\end{array}$ & 岕 & $\stackrel{\substack{n \\
\sim}}{\sim}$ & $\underset{\mathrm{N}}{\stackrel{N}{N}}$ & ลิ่ & ì & $\mid$ & হ్ & $\begin{array}{l}\text { ᄋ } \\
\text { ஸे }\end{array}$ & $\stackrel{\substack{0 \\
\sim}}{\sim}$ & $\underset{n}{\bar{n}}$ & $\stackrel{n}{\sim}$ & $\stackrel{\bar{\infty}}{\sim}$ & & 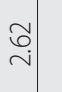 & $\stackrel{\Re}{\stackrel{7}{m}}$ \\
\hline \multirow{2}{*}{ 岂壳岕 } & 으 & 요 1 & f. & $\bar{\infty}_{.}$ & 으. & ثึ? & ○. & 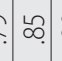 & $\infty$ & $\tilde{\sigma}$ & $\infty$ & 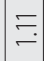 & के & ø! & $\stackrel{\infty}{\infty}$ & 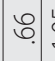 & $\stackrel{\text { L }}{\circ}$ & $\widetilde{\sigma}$ \\
\hline & 孚 & $\stackrel{\infty}{m}$ & $\underset{m}{\stackrel{N}{N}}$ & $\stackrel{?}{i}$ & ํ. & 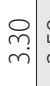 & $\stackrel{\infty}{\sim} \underset{\substack{\sim \\
\hdashline}}{\infty}$ & 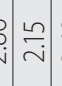 & $\mid \begin{array}{c}\infty \\
\stackrel{\infty}{0} \\
\sim\end{array}$ & 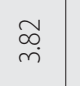 & $\stackrel{\curvearrowright}{\text { กิ }}$ & 跓 & $\stackrel{\stackrel{\varrho}{n}}{m}$ & 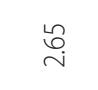 & $\stackrel{b}{m}$ & $\begin{array}{c}\stackrel{\sim}{\infty} \\
\sim\end{array}$ & 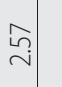 & $\stackrel{\Re}{\stackrel{q}{m}}$ \\
\hline \multirow{2}{*}{ 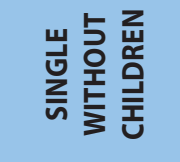 } & ㅇ & $\infty$ & $\stackrel{\infty}{\stackrel{\infty}{\uparrow}}$ & $\begin{array}{l}\infty \\
\infty . \\
\infty\end{array}$ & ๑. & ઠ) & ৪. & ஒ. & $\stackrel{n}{\stackrel{n}{n} .}$ & นn & $\stackrel{\infty}{\circ}$ & ळ. & $\stackrel{\llcorner}{\infty}$ & శక & 吕 & $\bar{\infty}$. & œ & ळి \\
\hline & 胥 & సે & $\begin{array}{l}\stackrel{v}{6} \\
\text { m. }\end{array}$ & $\stackrel{\Upsilon}{\sim}$ & 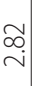 & $\left.\begin{array}{l}\infty \\
\infty \\
\sim \\
\sim\end{array}\right]$ & ¿্ঠి & 교 고 & 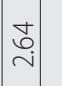 & 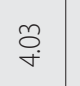 & Љ্ & 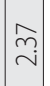 & $\underset{\sim}{\tilde{n}}$ & 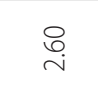 & $\stackrel{\infty}{\stackrel{\infty}{\sim}}$ & & 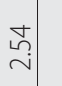 & $\stackrel{\infty}{m}$ \\
\hline \multirow{2}{*}{ 亭 } & a & 艾 & $\stackrel{n}{\sigma}$ & $\stackrel{m}{t}$ & 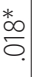 & $\stackrel{m}{=}$ & 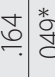 & 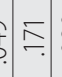 & $\begin{array}{l}0 \\
\infty \\
0\end{array}$ & ஜ̊. & $\stackrel{\infty}{\infty}$ & $\begin{array}{l}* \\
0 \\
\Xi \\
\partial\end{array}$ & $\stackrel{\overbrace{}}{\text { ஸे }}$ & ఫ̛ & 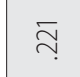 & ప్రి & ฮै & $\begin{array}{l}\infty \\
ٍ \\
\varnothing\end{array}$ \\
\hline & แ & $\underset{n}{\tilde{m}}$ & 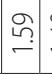 & 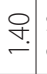 & $\begin{array}{l}\stackrel{ }{+} \\
\dot{m}\end{array}$ & $\stackrel{\infty}{\infty}$ & $\underset{\Sigma}{\Sigma} \tilde{c}$ & 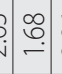 & 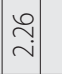 & $\stackrel{\sim}{\sim}$ & $\bar{m}$ & $\begin{array}{l}\bullet \\
\dot{m} \\
\dot{m}\end{array}$ & $\stackrel{\sim}{n}$ & ำ & 守 & $\overline{0}$ & $\begin{array}{l}\infty \\
\infty \\
\infty \\
+ \\
\end{array}$ & กุ \\
\hline \multirow{2}{*}{ 䍃 } & ท & ১. & 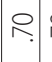 & 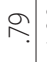 & ㅇ. & ळ. & চ. & 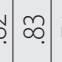 & N & $\stackrel{n}{\circ}$ & ळ & 吕 & ஓా. & $\wedge$ & $\stackrel{\sim}{\infty}$ & হ & ळ. & ळి. \\
\hline & 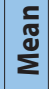 & m. & $\left|\begin{array}{l}\hat{\sigma} \\
\dot{b} \\
m\end{array}\right|$ & ৪. & $\stackrel{\curvearrowright}{\mathrm{N}}$ & 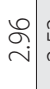 & น & 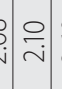 & $\begin{array}{l}8 \\
0 \\
ن\end{array}$ & $\stackrel{m}{m}$ & ๙ิ & D్ర & $\stackrel{\text { సે }}{n}$ & 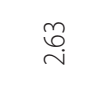 & 옥 & $\underset{\sim}{\bar{\sigma}}$ & فे & 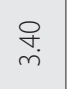 \\
\hline \multirow{2}{*}{ 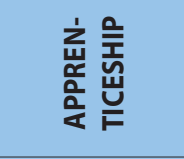 } & ท & $\stackrel{\infty}{\Upsilon}$ & के & ৪. & ळे! & 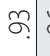 & ๑. & \begin{tabular}{ll}
0 \\
\hdashline
\end{tabular} & I & $\hat{\sigma}$ & ळ. & $\stackrel{0}{\circ}$ & $\bar{\sigma}$ & $\underset{\odot}{\sigma}$ & $\cong$ & $\infty$ & œ. & ஜ \\
\hline & 趂 & ๙े & N̦ & $\stackrel{\infty}{\stackrel{\infty}{\sim}}$ & 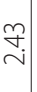 & $\stackrel{\overbrace \sim ్}{\sim}$ & $\underset{\sim}{\sigma} \overbrace{}^{\infty}$ & $\stackrel{s}{\stackrel{\circ}{\sim}}$ & $\underset{\mathrm{N}}{\mathrm{N}}$ & $\stackrel{\bar{\infty}}{\dot{m}^{\prime}}$ & ડ્ડ & $\begin{array}{l}0 \\
\infty \\
\sim \\
\sim\end{array}$ & $\stackrel{\sim}{\check{m}}$ & $\stackrel{n}{\sim}$ & $\bar{\sigma}_{\dot{m}}$ & 冬 & $\stackrel{\stackrel{\Im}{\sim}}{\sim}$ & 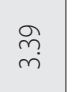 \\
\hline \multirow{2}{*}{$\begin{array}{l}\text { 종 응 } \\
\text { 오는 }\end{array}$} & 只 & $\infty$. & $\infty$ & $\stackrel{\text { : }}{-}$ & ๙़! & $\stackrel{m}{-}$ & के श & ৪! & 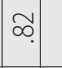 & $\stackrel{+}{\circ}$ & $\stackrel{ \pm}{\stackrel{ \pm}{\leftrightarrows}}$ & ŏ & $\stackrel{\text { L }}{\infty}$ & ஓ & ๙ & $\approx$. & ๑. & œ \\
\hline & 趂 & $\underset{m}{m}$ & $\mid \begin{array}{c}\tilde{N} \\
m \\
m\end{array}$ & $\stackrel{\bar{\infty}}{\sim}$ & $\stackrel{\overbrace{}}{\sim}$ & $\stackrel{\diamond}{\diamond}$ & ๑̊. & $\stackrel{s}{\stackrel{\sim}{\sim}} \underset{\sim}{\sim}$ & $\begin{array}{c}\infty \\
\stackrel{\sim}{\sim}\end{array}$ & $\underset{\sim}{\mathscr{O}}$ & $\stackrel{\infty}{\Im}$ & 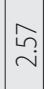 & $\stackrel{\equiv}{\bar{m}}$ & $\stackrel{\stackrel{\llcorner}{\sim}}{\sim}$ & $\stackrel{\widehat{i}}{\widehat{i}}$ & 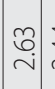 & $\underset{\sim}{\stackrel{\nabla}{v}}$ & 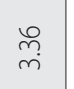 \\
\hline \multirow{2}{*}{ 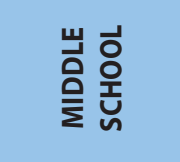 } & ท & $\overline{-}$ & $\pi$ & ర․․ & 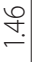 & $\stackrel{\overbrace{}}{-}$ & \begin{tabular}{c|rc}
$\infty$ & \multirow{2}{*}{}
\end{tabular} & $\begin{array}{l}\infty \\
\infty \\
\infty\end{array}$ & $\stackrel{n}{\Re}$ & $\stackrel{ \pm}{\longleftarrow}$ & $\bar{\lambda}$ & 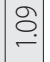 & જ! & ৪! & চু & 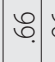 & ৫) & 8 \\
\hline & 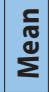 & 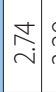 & 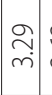 & 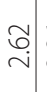 & 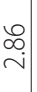 & $\stackrel{\nabla}{\stackrel{\nabla}{~}}$ & ন্ড & $\grave{i}$ & 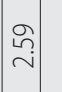 & $\stackrel{\leftrightarrow}{\stackrel{n}{n}}$ & $\stackrel{\infty}{\sim}$ & 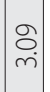 & $\underset{m}{\bar{m}}$ & $\stackrel{\nabla}{\stackrel{N}{N}}$ & 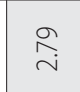 & $\mid \stackrel{\widehat{\infty}}{\sim}$ & ๗ે. & $\stackrel{\sim}{\tilde{b}}$ \\
\hline \multirow[t]{2}{*}{ 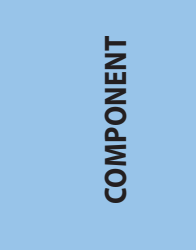 } & & $\frac{\pi}{a}$ & 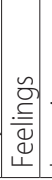 & . & & 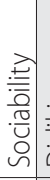 & 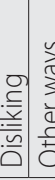 & 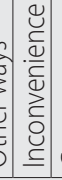 & 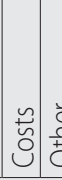 & 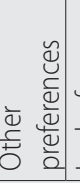 & 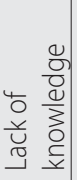 & 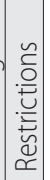 & 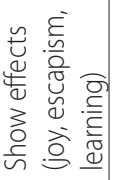 & 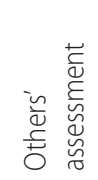 & 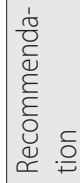 & 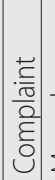 & 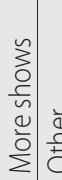 & 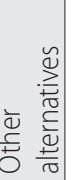 \\
\hline & & & & & & & & & & 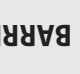 & & & $\begin{array}{r}\exists \cap \\
0 \exists \wedge 1\end{array}$ & $\begin{array}{l}\forall \Lambda \\
\text { כy }\end{array}$ & & & I & \\
\hline
\end{tabular}


consumption of a show are considered, differences between men and women were found in the case of these three barriers: disliking, other preferences, and lack of knowledge, all scoring significantly higher among men than among women. As for perceived value, women evaluated both perceived value dimensions (i.e. show effects and others' assessment) higher than did men. Finally, significant differences were found for intentions to recommend and intentions to attend more dance shows, and both were assessed better by female than by male respondents. On the other hand, men show a stronger intention to complain than do women and seem more inclined to opt for other alternatives. However, these two differences were not statistically significant (see Table 7).

In the case of age, the only significant difference among the four established groups was obtained for the restrictions dimension of barriers, which was the highest among the oldest respondents (30-35 years old) and the lowest among respondents aged between 22 and 25 years (see Table 7).

Few differences may also be observed where the education level is concerned, mostly between the respondents holding a university degree and those with middle school diploma; the former showed higher play motives and intentions to visit more shows, while the latter gave higher scores to the other ways barriers dimension (see Table 8).

Finally, the sociability component of motives and other preferences and restrictions components of barriers were assessed differently when the marital status of respondents was considered. Namely, single people with children seem to be much more motivated to visit a dance show than people in a relationship and without children. In addition, for single people with children, restrictions are confirmed as the most relevant barrier, while for singles without children that seems to be the least important barrier. On the other hand, for singles without children, other preferences emerge as the strongest barrier to see a dance show, while for those in a relationship and with children they do not appear to be as relevant because this particular inhibitor had the lowest mean value in that group (see Table 8).

\section{CONCLUSIONS}

By adopting this experiential approach, findings of this study reveal that motives for the consumption of dance shows can be classified into five components (play, feelings, learning, interests, and sociability), while barriers are composed of seven factors (disliking, other ways, inconvenience, costs, other preferences, lack of knowledge, and restrictions). Furthermore, perceived value can be assessed through show effects (joy, liking, escapism, learning) and others' assessment, whereas intentions can be categorized into intentions to recommend, intentions to complain, intentions to attend more dance shows, and intentions to attend other alternatives.

The result of factor analysis conducted on the four core variables of this study (motives, barriers, perceived value and intentions) show that feelings are the major motive, while other preferences are the main barrier to attend a dance show. In addition, show effects emerge as the most relevant dimension of perceived value. These value dimensions correspond to joy, escapism, and learning, which are experiential drivers of consumer assessment. Concerning the balance between utilitarian and hedonic values, the latter prevail, demonstrating what our results confirm that dance consumption can be understood as fully experiential. As regarding intentions, surprisingly, people are more inclined to complain than to visit more shows, and seem to prefer other alternatives over a dance show in the future. This result calls for further replications to fully confirm this one-time preference.

Gender is confirmed as the main moderating variable, with significant differences found between men and women with regard to all the examined variables. In particular, women appear to be significantly more motivated than men,
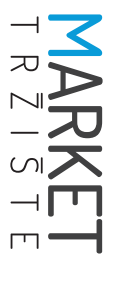
regardless of motive (play, feelings, learning, or interest). Also, men perceive some barriers significantly differently than women. More specifically, results reveal that disliking, other preferences, and lack of knowledge are significantly stronger barriers for men than for women. In addition, women attribute higher scores to perceived value, i.e. to show effects and others' assessment, showing also that experiential value assessments are highly personal (in our case varying by gender, but not by age or educational level and marital status). Women also have stronger intentions to recommend and to visit more shows. These results confirm the multidimensionality and high subjectivity of the perceived value of a dance show, highlighting its affective and emotional aspect. Other works applying value dimensionality have found similar variability by gender for diverse settings, such as mobile phones (e.g. Andrews, Drennan \& Russell-Bennett, 2012), full service restaurants (e.g. Jin, Line \& Goh, 2013), or student trips (e.g. Gallarza \& Gil-Saura, 2008). In sum, our results cohere with the nature of the experiential approach and with the basically personal aspect of consumer value (Holbrook, 1999), suggesting that people differ in their preferences, thus providing important implications for segmentation approach.

Further replications of the study should concentrate on the feminine bias found on perceived value, positive recommendations, and repurchase intentions, as well as on the effect of other variables such as age in order to better understand prominent segments of dance consumers. In addition, future contributions should overcome certain limitations that this paper presents, such as its exploratory nature, the non-probability sampling method used, the limited area of research, and the narrow population addressed.

Finally, results could be of certain relevance for marketing managers or program planners at performing arts venues. Owing to the fact that dance is more appealing to women, they should target this segment to a greater extent by updating their programs. Among other options, dance performances more focused on women's personal interests as well as on other enhancing feelings and emotions, as these are the main goals of their attendance, or shows with new and different discourses and styles suited to their interest in learning, could be included in the programs. In other words, loyalty appears necessary to increase the frequency of attendance of this group. In this sense, tailored promotional campaigns - possibly via online direct marketing, as digital media are often used as sources of information regarding performing arts - are highly relevant. Satisfied attendees could also act as ambassadors, motivating only women but also men to attend dance shows in the medium run.

\section{ACKNOWLEDGMENTS}

This research was conducted under the projects UV-SFPIE_RMD16-418790 and UV-SFPIE_RMD17586254, funded by University of Valencia, Office of the Vice-Principal for Training Policies and Educational Quality.

\section{References}

1. Addis, M., \& Holbrook, M. B. (2010). Consumers' identification and beyond: Attraction, reverence, and escapism in the evaluation of films. Psychology and Marketing, 27(9), 821-845.

2. Allard, T., Babin, B. J., \& Chebat, J. (2009). When income matters: Customers evaluation of shopping malls' hedonic and utilitarian orientations. Journal of Retailing and Consumer Services, 16(1), 40-49.

3. Andrews, L., Drennan, J., \& Russell-Bennett, R. (2012). Linking perceived value of mobile marketing with the experiential consumption of mobile phones. European Journal of Marketing, 46(3/4), 357-386. 
4. Andrews, L., Kiel, G., Drennan, J., Boyle, M., \& Werawardeena, J. (2007). Gendered perceptions of experiential value in using web-based retail channels. European Journal of Marketing, 41(5/6), 640-658.

5. Arnold, M. J., \& Reynolds, K. E. (2003). Hedonic shopping motivations. Journal of Retailing, 79(2), 77-95.

6. Arnould, E. (2007). Consuming experience. Retrospects and prospects. In: A. Carú \& B. Cova (eds), Consuming Experience (pp. 185-194), London: Routledge.

7. Babin, B. J., Darden, W. R., \& Griffin, M. (1994): Work and/or fun: measuring hedonic and utilitarian shopping value. Journal of Consumer Research 20(4), 644-656.

8. Bendinghaus, T. (2016). What is contemporary dance? Retrieved from: http://dance.about.com/ od/typesofdance/f/What-Is-Contemporary-Dance.htm.

9. Bigné, J. E., Andreu, L., \& Matilla A. (2008). The impact of experiential consumption cognitions and emotions on behavioral intentions. Journal of Services Marketing, 22(4), 303-315.

10. Clarke, J. (2013). Experiential aspects of tourism gift consumption. Journal of Vacation Marketing, 19(1), 75-87.

11. Cuadrado-García, M., Pérez-Cabañero, C., \& Montoro-Pons, J. D. (2017). Managing satisfaction in cultural events. Exploring the role of core and peripheral product. Management: Journal of Contemporary Management Issues, 22(1), 157-174.

12. European Commission. Directorate-General for Education - Eurobarometer (2013). Cultural access and participation report. Special Eurobarometer 399.

13. Gallarza, M. G., Arteaga-Moreno, F., Servera-Francés, D., \& Fayos-Gardó, T. (2016). Volunteering for special events: Comparison between expected and perceived values. Innovar, 26(59), 47-60.

14. Gallarza, M. G., \& Gil-Saura, I. (2008). The concept of value and its dimensions: A tool for analysing tourism experiences. Tourism Review, 63(3), 4-20.

15. Gallarza, M. G., Gil-Saura, I., \& Holbrook, M. B. (2011). The value of value: Further excursions on the meaning and role of customer value. Journal of Consumer Behavior, 10(4), 179-191.

16. Helkkula, A., Kelleher, C., \& Pihlström, M. (2012). Characterizing value as an experience: implications for service researchers and managers. Journal of Service Research, 15(1), $59-75$.

17. Holbrook, M. B. (1999). Consumer value: A framework for analysis and research. London: Routledge.

18. Holbrook, M. B. (2009). A cinemusicaliterary analysis of the American dream as represented by biographical jazz comedepictions in the golden age of Hollywood biopics. Marketing Theory, 9(3), 259-313.

19. Holbrook, M. B., \& Hirschman, E. C. (1982). The experiential aspects of consumption: consumer fantasies, feelings and fun. Journal of Consumer Research, 9(2), 132-140.

20. Jackson, V., Stoel, L., \& Brantley, A. (2011). Mall attributes and shopping value: Differences by gender and generational cohort. Journal of Retailing and Consumer Services, 18(1), 1-9.

21. Jin, N. P., Line, N. D., \& Goh, B. (2013). Experiential value, relationship quality, and customer loyalty in full-service restaurants: The moderating role of gender. Journal of Hospitality Marketing \& Management, 22(7), 679-700.

22. Kivetz, R., \& Strahilevitz, M. (2001). Factors affecting consumer choices between hedonic and utilitarian options. Advances in Consumer Research, 28(1), 325.

23. Komarac, T. (2014). A new world for museum marketing? Facing the old dilemmas while challenging new market opportunities. Tržište-Market, 26(2), 199-214.

24. Lloyd, A. E., Yip, L. S. C., \& Luk, S. T. K. (2011). An examination of the differences in retail service evaluation between domestic and tourist shoppers in Hong Kong. Tourism Management, 32(3), 520-533.

25. Mathwick, C., Malhotra, N., \& Rigdon, E. (2001). Experiential value: conceptualization, measurement and application in the catalog and internet shopping environment. Journal of Retailing, 77(1), 3-56. 
26. Otto, J. E., \& Ritchie, J. R. B. (1996). The service experience in tourism. Tourism Management, 17, 165-174.

27. Petermans, A., Janssens, W., \& Van Cleempoel, K. (2013). A holistic framework for conceptualizing customer experiences in retail environments. International Journal of Design, 7(2), 1-18.

28. Sánchez-Fernández, R., Iniesta-Bonillo, M. A., \& Holbrook, M. B. (2009). The conceptualisation and measurement of consumer value in services. International Journal of Market Research, 51(1), 93-113.

29. Schmitt, B. H. (1999). Experiential marketing. How to get customers to sense, feel, think, act, relate. New York, NY: The Free Press.

30. Seo, S., \& Lee, Y. (2008). Shopping values of clothing retailers perceived by consumers of different social classes. Journal of Retailing and Consumer Services, 15(6), 491-499.

31. Seo, Y. (2013). Electronic sports: A new marketing landscape of the experience economy. Journal of Marketing Management, 29(13/14), 1542-1560.

32. SGAE (2017). Anuario SGAE de las artes escénicas, musicales y audiovisuales. Fundación SGAE. Retrieved from: http://www.anuariossgae.com/anuario2017/home.html.

33. Sheth, J. N., Newman, B. I., \& Gross, B. L. (1991). Why we buy what we buy: a theory of consumption values. Journal of Business Research, 22(2), 159-170.

34. Sørensen, F., \& Jensen, J. F. (2015): Value creation and knowledge development in tourism experience encounters. Tourism Management, 46, 336-346.

35. Sullivan, P., Bonn, M. A., Bhardwaj, V., \& DuPont, A. (2012). Mexican national cross-border shopping: Exploration of retail tourism. Journal of Retailing and Consumer Services, 19(6), 596-604.

36. Sweeney, J. C., \& Soutar, G. N. (2001). Consumer perceived value: The development of a multiple item scale. Journal of Retailing, 7(2), 203-220.

37. Theodorakis, N., Goulimaris, D., \& Gargalianos, D. (2003). The relationship between service quality and behavioral intentions for spectators at traditional dance performances in Greece. World Leisure Journal, 45(1), 53-61.

38. Woodward, M. N., \& Holbrook, M. B. (2013). Dialogue on some concepts, definitions and issues pertaining to 'consumption experiences. Marketing Theory, 13(3), 323-344.

39. Yuan, Y. H., \&Wu, C. K. (2008). Relationship among experiential marketing, experiential value, and customer satisfaction. Journal of Hospitality and Tourism Research, 32(3), 387-410.

40. Zeithaml, V. A. (1988). Consumer perceptions of price, quality, and value: a means-end model and synthesis of evidence. Journal of Marketing, 52(3), 2-22. 